\title{
Macroeconomic and Bank-Specific Variables and the Liquidity of Jordanian Commercial Banks
}

\author{
Ali Mustafa AL-QUDAH ${ }^{1}$ \\ Received: September 01, 2020 Revised: October 26, 2020 Accepted: November 05, 2020
}

\begin{abstract}
This study aimed to explore the impact of macroeconomic (Real GDP growth (GDPG), Inflation rate (INF)) and bank -specific variables (profitability (ROA), capital adequacy (CADEQ), non-performing loans (NPL), deposit growth (DEPG)) on the liquidity (IIQ) of 13 listed Jordanian commercial banks for the period 2011-2018. Panel data analysis, Pooled least square, fixed effects model and random effects model, Lagrange multiplier test, and Hausman test were used. The random effects model output shows that, macroeconomic variables have a significant impact on Jordanian commercial banks liquidity since inflation has a positive impact while GDPG has a negative impact on banks (LIQ). On the other hand among the bank-specific variables capital adequacy and deposit growth have a positive significant impact on banks (LIQ), while (NPL) and (SIZE) have a negative significant impact on Jordanian commercial banks liquidity. But ROA has a negative insignificant impact on (LIQ). The findings of the study suggest that commercial banks departments need to pay attention to the economic and internal variables of banks in order to maintain acceptable levels of liquidity.
\end{abstract}

Keywords: Banks, Macroeconomic, Bank-Specific, Panel Data, Liquidity

JEL Classification Code: G21, G33, G01

\section{Introduction}

Commercial banks are considered as a fundamental pillar of the financial system of any country, as they play an important and effective role as a financial intermediary between surplus and deficit destinations, and they continuously work to develop their environment, banking tools and activities to keep pace with rapid development in the world (Demirguc-Kunt \& Huizinga, 1998). It mainly accepts deposits of various types, current, time and savings, and then converts these deposits into short and long-term loans. This undoubtedly may expose commercial banks to liquidity risk, especially with the constant possibility that the clients suddenly withdraw their deposits. Desrochers and Prefontaine, (2008) defined liquidity as the bank's ability to

${ }^{1}$ First Author and Corresponding Author. Associate Professor, Department of Finance and Business Economics, Faculty of Economics and Administrative Sciences, Al Al-Bayt University, Mafraq, Jordan [Postal Address: Al-Mafraq, Jordan] Email: alimqf@yahoo.com

(C) Copyright: The Author(s)

This is an Open Access article distributed under the terms of the Creative Commons Attribution Non-Commercial License (https://creativecommons.org/licenses/by-nc/4.0/) which permits unrestricted non-commercial use, distribution, and reproduction in any medium, provided the original work is properly cited. finance the increase in assets and meet its liabilities when due without incurring large or unacceptable losses. While the definition of liquidity risk is the inability of the bank to fulfill its obligations when they fall due without adversely affecting the financial position of the bank.

Therefore, commercial banks must provide adequate liquidity (LIQ) for their banking operations, taking into account not to maintain large amounts of (LIQ) that are greater than the bank's need, which is negatively reflected on the operation of the bank's funds and subsequently on the bank's financial performance. Liquidity is closely related to the effectiveness of banking operations, which may affect its financial solvency, which in turn may lead to bankruptcy in the event of low levels of liquidity. It may also lead to lower rates of profitability in the event that liquidity rates may rise above the desired levels that are consistent with the size of the bank's banking activity, which will undoubtedly negatively affect shareholders' equity.

The world financial crisis of the year (2008) occurred as a result of the subprime mortgage crisis in the USA, rapidly turned into a liquidity crisis in American banks and other banks around the world associated with this issue, which caused bankruptcy of dozens of banks in USA. The world financial crisis of 2008 demonstrated the urgent need for 
banks to set a reasonable level of liquidity to meet adequate emergency conditions (Nguyen \& Dang, 2020; Ferrouhi, \& Lahadiri, 2014). This is because the lack of liquidity in critical circumstances leads to bankruptcy of the bank.

Since the world financial crisis (2008) and the bankruptcy of many banks and financial institutions around the world, interest in (LIQ) and its risks has increased in the departments of commercial banks and central banks around the world in order to spare commercial banks the threat of bankruptcy and the destruction collapse of their financial system. Although the goal of commercial banks is to maximize their profits and the wealth of owners, maintaining adequate (LIQ) is also equally important because of its implications for the work of banks and their financial performance and the economy as a whole (Goodhart, 2008).

Liquidity risk is one of the most important risks that commercial banks face. Economic and political changes have increased its importance and influence banks. Jordanian banks, like other banks around the world, face the challenges of (LIQ) risks and the procedures to be taken to ensure the continued safety of banks. Jordanian banks, like other banks, may be exposed to sudden withdrawals from time to time by depositors for various reasons.

One of the motives for studying the variables that impact significantly on (LIQ). Is that it receives great attention from the day-to-day management of banks, as it exists in different ratios on the bank's balance sheet and determines its main (LIQ) trends. It also reflects the reality of the bank's (LIQ), represented by the bank's ability to provide adequate financing in a short period of time and at a low cost. Such as the bank holding cash reserves, or government securities or maintaining large amounts of stable liabilities such as retail deposits (Vodova, 2011).

The second motive is of the view about the major role that the Jordanian banking sector plays in economic life since the Jordanian economy depends mainly on banks, as they are the main financiers of economic development in Jordan. Banks constitute more than $95 \%$ of the sources of financing in Jordan. Where credit facilities granted to the public and private sectors exceed 27 billion Jordanian dinars, its deposits exceed 35 billion Jordanian dinars, and its assets exceed 53 billion dinars by the end of 2019. Banks are also implementing the directions of the monetary policy in Jordan and reflecting them on the Jordanian economy. The objective of the current study is to identify the macroeconomic and bank-Specific variables that significantly affect the (LIQ) of the 13 Jordanian commercial banks listed on the Amman Stock Exchange (ASE) for the period 2011-2018 by using panel data analysis.

This study consists of five sections. Section One Introduction, Section- Two- Literature review, Section ThreeData and Methodology, Section Four- Empirical analysis results and discussion, and Section Five- Conclusions and recommendations.

\section{Literature Review}

\subsection{Theoretical Literature}

Diamond and Rajan, (2001) defined banks (LIQ) as the degree of ease of converting assets into cash so that banks can meet their obligations on time without incurring any unacceptable losses. Liquidity can also be defined as the cash available with the banks to meet requests for withdrawal from depositors or requests for borrowers when granting credit to individuals, companies, or the government. Through the previous definitions of (LIQ), it is clear that (LIQ) is a vital issue for the banks. Therefore, banks must pay great attention to the (LIQ) position they have during carrying out their various banking operations by keeping sufficient quantities of liquid assets such as cash and various reserves in their budgets that can be easily converted into cash when needed or through the market to ensure their ability to meet customers' demands.

The researchers distinguish between two types of liquidity. The first type is financing (LIQ), which means the bank's ability to provide the necessary funds to finance its expected and unexpected obligations at an acceptable cost. As for the second type it is market (LIQ), which means the bank's ability to save money by liquidating its assets instead of borrowing. If this liquidity is low, then the liquidation process of assets will take place at prices lower than the expected prices (Bonner et al., 2015).

Fleming (1974) believes that banks tend to hold liquid funds in order to meet the expected cash withdrawal requests of depositors, to meet the increasing demands on borrowing from various clients, to provide payment for services provided by banks or authorities, and finally to meet the legal reserve requirements imposed by central banks on banks.

We can say that the success of banks is mainly related to the extent of customer confidence in them, through providing the necessary liquidity. To meet the demands of depositors and borrowers alike, which depends on the ability of banks to convert their assets into (LIQ) without losing their value.

The basic traditional business of banks is to convert deposits (liquid liabilities) into loans (non-liquid assets), which creates a maturity gap due to the existence of different maturity periods and also affects the bank's (LIQ) position. Therefore, banks tend to reduce this maturity gap by holding liquid assets (Diamond \& Dybvig, 1983). This work that banks do on a permanent basis exposes them to what is known as liquidity risk. Liquidity risk is seen as a normal matter of day-to-day bank management.

Banks require to control its (LIQ) and ensure its sufficiency in order to pay the promised customer deposits immediately or fulfill the expected loan obligations. This liquidity risk may remain threatening to the solvency of the bank if it completely fails to provide the required (LIQ) to repay the promised deposits (Saunders et al., 2006). 
The (LIQ) risk is measured by the liquidity gap and the liquidity ratios. The (LIQ) gap is defined as the difference between assets and liabilities now and in the future, and a positive gap is equal to the deficit (Bessis, 2009). As for as the (LIQ) ratios are concerned, they are different ratios in the balance sheet that determine (LIQ) trends. There are a number of authors such as Moore, (2009); Rychtarik, (2009); Praet and Herzberg, (2008) who have provided different bank liquidity ratios. To show the (LIQ) determinants of commercial banks, there are two methods which are the (LIQ) gap method and the (LIQ) ratios method. Most researchers believe that liquidity ratios are the most used in studies because they are more typical, where these ratios are the ratio of liquid assets to total assets, the ratio of liquid assets to deposits and short term borrowing, the ratio of loans to total assets and the ratio of loans to deposits and short term borrowing (Vodova, 2013 ).

\subsection{Empirical Evidence}

Through the literature review, there are a number of studies related to the current study that dealt with the determinants or variables affecting the (LIQ) of commercial banks around the world, including that of Al-Homaidi, et al., (2019) who examined (LIQ) determinants of 37 banks in India over the period 2008-2017. The output of panel data analysis indicated that capital adequacy (CADEQ), bank size, and ROA, deposit ratio, have a positive significant impact on (LIQ). While asset quality and ROE have negative impacts.

Assfaw (2019) tests determined banks (LIQ) in Ethiopia for the period 2011-2017. The researchers found out that the bank size, deposits, loans, GDP, and inflation are determinants of bank (LIQ).

Gjorgi and Goran (2019), tested the (LIQ) determinants of banks in Macedonia. The study covered the period 20072017 and used the GMM method for the analysis. They proved that profitability and non-performing loans have a positive effect on banks' (LIQ). While the size of the bank has a negative effect. But the adequacy of capital and GDP had no effect on the (LIQ) of the banks.

Khanal (2019) examined the determinants of (LIQ) for 10 Nepalese commercial banks. The study used panel data analysis for the period 2017 to 2016 . The regression results revealed that ROA has a positive significant impact on banks (LIQ). ROE, Size and inflation have negative and significant impact on Nepalese commercial banks (LIQ).

Al-Homaidi, et al., (2019) they tested the determinants of (LIQ) of Indian banks for the period 2008-2017 and used panel analysis. The results indicated that capital adequacy, bank size, ROA, and deposit ratio have a positive effect on banks' (LIQ). But ROE and GDP have a negative effect.
Shah, et al., (2018) examined a number of variables affecting the (LIQ) of banks in Pakistan for the period 20072016. The study concluded that GDP, bank size, and capital adequacy have a positive effect on banks (LIQ).

Al-Harbi (2017) defined the determinants of bank (LIQ) in the (IOCC), using the fixed effects model. The study showed that deposit insurance, monetary policy, capital ratio, credit risk and inflation had a negative impact, while market value, efficiency and size had a positive effect on (LIQ).

Sheefeni, J and Nyambe, J. (2016) examined the macroeconomic determinants of banks (LIQ) in Namibia. A dynamic error correction model was used to analyze quarterly data for the period 2001-2014. The results indicated the real GDP is the determinant of banks (LIQ).

The study of Mashamba, (2014) explored the internal determinants of Zimbabwean banks (LIQ) by using OLS method. The study find that the non-performing loans (NPL) has a negative relationship with (LIQ). While bank size and capital adequacy (CADEQ) have a positive relationship with liquidity.

Vodova (2011) identified the liquidity determinants of banks (LIQ) in the Czech Republic for the period 20012009 using panel data. The researcher concluded that capital adequacy and (NPL) have a positive effect on (LIQ), while inflation and financial crisis have a negative effect. But the size of the bank has an ambiguous effect.

Previous studies have shown that most of them were conducted after the global financial crisis. Some of them deal with macroeconomic variables. Some dealt with the internal variables of the bank, and others dealt with macroeconomic and microeconomic variables with a difference in the number of variables. Most of the previous studies did not address the effect of deposits growth in their entirety on bank liquidity, noting that they express the main activity of banks as a financial intermediary. Therefore this study used deposits growth to provide additional evidence of its importance as a determinant of (LIQ), which was in addition to the best knowledge of the researcher. This is the first study that deals with testing the macroeconomic and bank-specific variables on (LIQ) of the 13 Jordanian commercial banks listed on the (ASE) for the period 2011-2018.

\subsection{Hypotheses}

Based on the literature review, the suggested assumptions for this study are:

H1: macroeconomic variables (Real GDP growth and inflation) significantly impact listed Jordanian commercial banks' liquidity.

H2: Bank-specific variables (Profitability, bank size, capital adequacy ratio, non-performing loans ratio, and deposit growth) significantly impact listed Jordanian commercial banks' liquidity. 


\section{Data and Methodology}

\subsection{Data}

The Jordan banking sector consists of 24 banks, including three Islamic banks, eight foreign banks, and 13 Jordanian commercial banks. The 13 commercial banks of Jordan whose data are available for study in (ASE) database, were selected as samples for the study. The data related to the bank-specific variables were taken from the (ASE) database. As for the data of the macroeconomics variables, they were taken from the database of the $(\mathrm{CBJ})$ and 10 software packages were used for the analysis.

\subsection{Methodology}

Based on the previous studies such as Vodova, (2013), AlHomaidi, et al., (2019) and Al-Harbi (2017), the current study used the following panel data model (1) to explore the impact of macroeconomic and bank-specific variables on liquidity for Jordan commercial banks. In the model bank liquidity (LIQ) is measured by the ratio of liquid assets/total assets. This indicator has been used for the bank's liquidity, as it is considered a direct indicator of liquidity. The indicator shows the bank's ability to provide liquidity and its safety. The high of this ratio means the lower level of liquidity risk for the bank (Tran \& Nguyen, 2020) is a function of bank size, return on assets, capital adequacy ratio, non-performing loans ratio, inflation rate, real GDP rate, and loans growth rate.

$$
\begin{aligned}
\text { LIQit } & =\alpha+\beta 1 \text { ROAit }+\beta 2 \text { SIZEit }+\beta 3 \text { CADEQit } \\
& +\beta 4 \text { NPLit }+\beta 5 \text { INFit }+\beta 6 \text { GDPGit } \\
& +\beta 7 \text { DEPGit }+ \text { Uit }
\end{aligned}
$$

Where LIQ (liquidity), dependent variable, bank $(i)$ and time $(t)$. constant $(\alpha)$, B1 - $\beta 7$ Parameters, (U) Error term.

\section{Results and Discussion}

\subsection{Correlation Matrix}

The correlation matrix reveals the correlation between the independent variables. This is because the presence of a multicollinearity problem between the independent variables makes it difficult to measure the role of each independent variable in explaining the difference in the value of the dependent variable. According to Kennedy (2008), a multicollinearity problem appears between the two independent variables if the value of the correlation coefficient is more than $80 \%$. Table (2) Shows that the correlation coefficient between the independent variables is less than $60 \%$, so, multicollinearity problem is not present.

Table 1: Definition of the Study Variables

\begin{tabular}{|l|l|}
\hline Dependent Variable & \\
\hline Liquidity ratio (LIQ) & $=$ liquid assets / total assets \\
\hline Independent Variables: & \\
\hline Return on assets (ROA) & $=$ net income / total assets \\
\hline Bank size (SIZE) & $=$ log total assets. \\
\hline Capital adequacy (CADEQ) & $=$ bank equity / total assets \\
\hline Non - performing loans ratio (NPL) & $=$ non - performing loans /total loans \\
\hline Inflation rate (INF) & $=$ percentage change in consumer price index \\
\hline Real GDP growth (GDPG) & $=$ percentage change in real GDP. \\
\hline Deposits growth (DEPG) & $=$ percentage change in deposits. \\
\hline
\end{tabular}

Table 2: Correlation Matrix

\begin{tabular}{|l|c|c|c|c|c|c|c|}
\hline & ROA & SIZE & CADEQ & NPL & INF & GDPG & DEPG \\
\hline ROA & 1 & & & & & & \\
\hline SIZE & 0.031575 & 1 & & & & & \\
\hline CADEQ & 0.550565 & 0.000686 & 1 & & & & \\
\hline NPL & -0.09169 & 0.000685 & 0.259657 & 1 & & & \\
\hline INF & -0.00978 & -0.05809 & 0.010264 & 0.245043 & 1 & & \\
\hline GDPG & 0.15275 & -0.10037 & 0.012827 & 0.223527 & 0.529955 & 1 & \\
\hline DEPG & 0.018014 & -0.07411 & -0.08147 & -0.51804 & -0.13159 & -0.05692 & 1 \\
\hline
\end{tabular}




\subsection{Descriptive Statistics}

Descriptive analysis helps to understand the behavior of variables during the study period. The descriptive analysis in Table (3) indicates the mean, highest and lowest and standard Deviation values of the LIQ, are (0.09), (0.22), (0.029), (0.041), respectively. This indicates that the average of (LIQ) ratio is $9 \%$, which is less than the minimum liquidity set by the (CBJ), which is $30 \%$ of Deposits.

ROA was taken to express the profitability of banks in order to show the performance of banks during the study period, where the average was 0.012 and the highest value reached $2.04 \%$ and the lowest value $-.01 \%$. For (CADEQ), the average was $14 \%$, the highest value reached $21 \%$ which is higher than $12 \%$, the minimum percentage imposed by the $(\mathrm{CBJ})$, and the lowest value is $7 \%$, its lower value is due to the period before raising the capital in 2014 according to the instructions of the Basel 3. For (NPL) the average value is 0.07 and the highest value reached is $25 \%$ which is more than $5 \%$, the percentage allowed by (CBJ) and the lowest value reached is $1.4 \% \%$. For the average value of growth in (DEPG) reached $6.2 \%$ and the highest value reached was $69 \%$, and the lowest value was -24 which dates back to the recession period that accompanied the World financial crisis as well as the Arab Spring, which led to a significant decline in interest rate.
Real GDP growth and inflation have been included to reflect the economic environment in Jordan. The average growth in GDP was 0.06 with the highest value reaching 0.09 and the lowest value was 0.03 . As for inflation, the average inflation was $2.8 \%$, the highest value reached was $4.7 \%$ and the lowest value reached $-0.8 \%$.

\subsection{Stationary Test}

Table (4) shows the results of testing the stationary of time series- cross-sectional data. . The results of Levin, Lind and Chu (LLC) test indicate that all the variables of the study are stationary at the level. Time-series stationary is a prerequisite for a good regression.

\subsection{Regression Results and Discussion}

The nature of the panel data used in this study is time series- cross-sectional data (panel data). Usually the Pooled Least squares and the Lagrange multiplier test are used in the first step. If the result of the Lagrange multiplier is statistically significant, this means that the fixed effects model (FEM) and the random effect model (REM) are appropriate, otherwise pooled least squares is suitable. The Hausman test is used to decide whether the (FEM) is appropriate or the (REM).

Table 3: Descriptive Statistics

\begin{tabular}{|l|c|c|c|c|c|c|c|c|}
\hline & LIQ & ROA & SIZE & CADEQ & NPL & INF & GDPG & DEPG \\
\hline Mean & 0.093566 & 0.01211 & 9.353203 & 0.140946 & 0.072059 & 0.028212 & 0.060561 & 0.06265 \\
\hline Median & 0.082852 & 0.012739 & 9.30722 & 0.140129 & 0.066687 & 0.03745 & 0.060228 & 0.05384 \\
\hline Maximum & 0.225306 & 0.020466 & 10.41262 & 0.21964 & 0.259277 & 0.04775 & 0.091387 & 0.69874 \\
\hline Minimum & 0.029939 & -0.00166 & 8.557473 & 0.075048 & 0.014641 & -0.00852 & 0.030311 & -.24865 \\
\hline Std. Dev. & 0.041007 & 0.004769 & 0.401996 & 0.02587 & 0.034141 & 0.021933 & 0.020976 & 0.159729 \\
\hline
\end{tabular}

Table 4: Levin, Lin \& Chu stationary test results

\begin{tabular}{|l|c|c|c|c|}
\hline Variable & LLC statistics & Probability & Level of Integration & Stationary \\
\hline LIQ & -3.0201 & $1 \%$ & $\mathrm{I}(0)$ & Stationary \\
\hline ROA & -2.23222 & $5 \%$ & $\mathrm{I}(0)$ & Stationary \\
\hline Size & -1.96573 & $5 \%$ & $\mathrm{I}(0)$ & Stationary \\
\hline CADEQ & -5.0757 & $1 \%$ & $\mathrm{I}(0)$ & Stationary \\
\hline NPL & -9.01855 & $1 \%$ & $\mathrm{I}(0)$ & Stationary \\
\hline INF & -9.13051 & $1 \%$ & $\mathrm{I}(0)$ & Stationary \\
\hline GDPG & -3.39171 & $1 \%$ & $\mathrm{I}(0)$ & Stationary \\
\hline DEPG & -3.77616 & $1 \%$ & $\mathrm{I}(0)$ & Stationary \\
\hline
\end{tabular}


If the result of Hausman's test is statistically significant, then this means that there is a serial correlation between the independent variables and the error term, and the (FEM) is the appropriate one, otherwise (REM) is appropriate (Gujarati \& Porter, 2009; Danila et al., 2020). In this study, the results of Lagrange multiplier are significant as listed in Table (5) and the Haussmann's test indicates that the (REM) is the appropriate model for estimation. Therefore, the (REM) was used to estimate the model.

The results of the analysis in Table (5) indicate that return on assets has a negative and insignificant effect on (LIQ). In other words, banks with high profits tend to maintain less (LIQ) this can be explained by the principle of trade-off between banking stability resulting from maintaining (LIQ) and high returns resulting from owning illiquid assets.

The results indicate that the size of the bank has a negative and significant effect on the (LIQ), where the value of the coefficient reached 1.29 and the significance of $1 \%$. This means that increasing the size of the bank by one unit will lead to an increase in (LIQ) by 1.29 units, the other things ceteris paribus. This result is consistent with the (too big to fail) hypothesis. If the big banks see themselves as too big to fail, their incentive to hold liquid funds is limited. In the event of a liquidity shortage, large banks rely on the lender of last resort as liquidity savers. This result is consistent with an outcome of (Al-Homaidi, 2019; Ojha, 2018; Gautam, 2016; Vadova, 2011; Mashmba, 2014) and is not consistent with an outcome of (Khanal, 2019; Shamas, et al., 2018).
As for capital adequacy (CADEQ), it has a positive significant effect on (LIQ), with a coefficient value of 1.09 and a significance of $1 \%$. This indicates that increasing the (CADEQ) by one unit will increase (LIQ) by 1.09 units if other things are held constant. Increasing (CADEQ) increases the liquidity of the bank, and this is consistent with the assumption that a bank with high capital adequacy should have high liquidity. The results are consistent with the findings of (Khanal, 2019; Ojha, 2018 Gautam, 2016; Vodova, 2011) and is not consistent with finding of (Mashmba, 2014).

The results also showed that the non-performing loans (NPL) ratio has a negative and significant effect on (LIQ), and the value of the coefficient reached 0.24 and the significance of $10 \%$, meaning that an increase by one unit in (NPL) will decrease (LIQ) by 0.24 unit if other things are held constant. This is because the customers' reluctance or inability to repay the loans owed to them, their interest, and the commissions imposed on them lead to the deprivation of banks of liquidity that is supposed to return to the bank on time to meet loans or withdrawals in return. It exposes the bank to the liquidity risk. The failure of customers to pay their debts in many countries of the world during the global financial crisis led to the bankruptcy of dozens of banks around the world due to the decline in the rates of liquidity in the banks to critical levels, with which banks have stopped continuing to carry out their business. The result is in line with the results of (Khanal, 2019; Gautam, 2016; Ojha, 2018; Shamas, et al., 2018), and not in line with results of (Gjorgi, 2019; Vodava, 2011; Mashmba, 2014).

Table 5: EGL (REM) Results for LIQ

\begin{tabular}{|c|c|c|c|c|}
\hline Variable & Coefficient & Std. Error & t-Statistic & Prob. \\
\hline C & 1.025335 & 0.180224 & 5.689221 & 0 \\
\hline ROA & -0.00202 & 0.93143 & -0.00217 & 0.9983 \\
\hline SIZE & -1.29891 & 0.077234 & -16.8179 & 0 \\
\hline CADEQ & 1.098982 & 0.197753 & 5.557359 & 0 \\
\hline NPL & -0.24835 & 0.128565 & -1.93168 & 0.0563 \\
\hline INF & 0.791854 & 0.185431 & 4.27035 & 0 \\
\hline GDPG & -0.54712 & 0.214087 & -2.55559 & 0.0122 \\
\hline DEPG & 1.289083 & 0.075124 & 17.15935 & 0 \\
\hline R-squared & 0.826086 & & & \\
\hline Adjusted R-squared & 0.813405 & & & \\
\hline S.E. of regression & 0.029191 & & & \\
\hline F-statistic & 65.1426 & & & \\
\hline Prob(F-statistic) & 0 & & & \\
\hline Huasman test Prob & 0.971 & & & \\
\hline LM-Breush-Pagan Prob & 0.0213 & & & \\
\hline
\end{tabular}


The results show that INF has a positive and significant effect on (LIQ) with a coefficient of 0.79 and a significance of $1 \%$. This is an indication that the increase in (INF) by one unit leads to increase (LIQ) by 0.79 unit. This is due to the fact that inflation leads to an increase in the interest rates and the cost of borrowing on the one hand, and on the other hand, inflation acts on the decline of economic activity and thus leads to a decline in the borrowing demand. Inflation also forces bank managements to follow a cautious credit policy. All of that reduces borrowing, which positively affect banks' liquidity. The finding is consistent with the findings of (Al-khori, 2012; Gautam, 2016; Ojha, 2018), and inconsistent with the findings of (Khanal, 2019; Vodova, 2011).

The results also indicated that the GDPG has a negative and significant impact on the liquidity of commercial banks in Jordan. One unit increase of GDPG leads to a decrease of (LIQ) by 0.54 units while other things remain constant. This means banks liquidity is inversely related to the economic cycle. In situations of economic boom, the demand for loans from individuals and companies increases. And banks that respond to the growing demand for loans will have their liquidity reduced. As for cases of economic downturn is concerned, the demand for loans decreases and the liquidity of banks increases. This finding is consistent with (AlHomaidi, 2019; Gautam, 2016; Vodova, 2011) and conflicts with the findings of (Khanal, 2018; Shah, et al., 2018; Alkhouri, 2012).

The results also show that deposit growth (DEPG) has a positive and significant effect on (LIQ), with a coefficient of 1.28 and a significance of $1 \%$. This indicates that increasing (DEPG) by one unit will increase (LIQ) by 1.28 units. This is due to the fact that most of the depositors in Jordanian commercial banks are merchants, industrial and service companies, universities, colleges, institutes and other public institutions with which it is difficult for commercial bank departments to predict the dates of their withdrawals, which forces banks to work at high liquidity rates. On the contrary, if the majority of depositors were individuals then forecasting would be easier, which would enable banks to operate at low liquidity rates. The result is in line with (Assfaw, 2019; AlHomaidi, 2019).

The Value of adjusted $\mathrm{R}$ square is $81 \%$ which indicates that the explanatory strength of the model is high, so that all the variables jointly explain $81 \%$ of the change in liquidity.

From Table 6, the results of the Breusch-Godfrey Serial Correlation LM Test, Heteroscedasticity Test: BreuschPagan-Godfrey prob. and normality tests Jarque-Pera shows that the probabilities of all of them is more than $5 \%$, which prooves that the model is a good model.
Table 6: Diagnostic test Results for the Model

\begin{tabular}{|l|c|}
\hline $\begin{array}{l}\text { Histogram-Normality } \\
\text { Test }\end{array}$ & Prob-Jarque-Pera- $=\mathbf{0 . 6 5 5 3 2 1}$ \\
\hline $\begin{array}{l}\text { Breusch-Godfrey } \\
\text { Serial Correlation LM } \\
\text { Test }\end{array}$ & prob- Chi -Square $=0.7371$ \\
\hline $\begin{array}{l}\text { Heteroskedasticity } \\
\text { Test: Breusch-Pagan- } \\
\text { Godfrey }\end{array}$ & Prob-Chi-Square =0.80122 \\
\hline
\end{tabular}

\section{Conclusions}

The aim of this study is to investigate the effect of the bank's macroeconomic and bank- specific variables that affect the liquidity of 13 Jordanian commercial banks listed on the (ASE) for the period 2011-2018. Cross-sectionaltime series data and the random effects model were used to estimate the effect of (profitability, bank size, capital adequacy, Non-performing loans, inflation, real GDP growth and deposit growth rate) on the (LIQ).The results of the analysis proved that the profitability of the bank has a negative relationship with LIQ which means banks with high profitability tends hold low liquid assets.

The results showed that the liquidity of Jordanian commercial banks increases with the increase in capital adequacy, inflation rates and deposit growth. The increase in capital adequacy indicates an increase in the liquid assets of banks. The increase in inflation rates, leads to an increase in the cost of borrowing, a decrease in it, and thus an increase in bank liquidity. The increase in deposit growth enhance banks liquidity because the majority of depositors are non-individuals, which forces banks to maintain high levels of liquidity to meet their requests, which are difficult to anticipate. On the other hand, the results showed that the liquidity of Jordanian commercial banks decreases with the increase in the size of the bank, non-performing loans and the growth rates in the real GDP. The increase in bank size is linked to a hypothesis that is (big to fail). This encourages banks to expand lending and reduce liquidity. While the increase in economic growth rates indicates that the Jordanian banks are inversely related to the economic cycles. Increasing deposit rates mainly increase the bank's liquid assets.

The study findings suggest that commercial banks departments should pay attention to the economic and internal variables of banks in order to maintain acceptable levels of liquidity. The study findings also suggests that the administrations of commercial banks in Jordan on the necessity of making a trade-off between lending and the bankruptcy risk. 


\section{References}

Al-Harbi, A. (2017). Determinants of banks liquidity: Evidence from OIC countries. Journal of Economic and Administrative Sciences, 33(2), 164-177. https://doi.org/10.1108/JEAS-022017-0004.

Al-Homaidi, E., Tabash, M., Farhan, N., \& Almaqtari, F. (2019). The Determinants of liquidity of Indian listed commercial banks: A panel data approach. Cogent Economics \& Finance, 7,1-20. https://www.tandfonline.com/loi/oaef20.

Al-Khouri, R. (2012). Bank characteristics and liquidity transformation: The case of GCC banks. International Journal of Economics and Finance, 4(12), 114-120. http://dx.doi. org/10.5539/ijef.v4n12p114.

Assfaw, A. (2019). Firm-specific and macroeconomic determinants of Banks Liquidity: Empirical investigation from Ethiopian private commercial banks. Journal of Accounting, Finance and Auditing Studies, 24, 123-145. https://jafas.org/ articles/2019-5-2/8_FULL_TEXT.pdf.

Bessis,J. (2009). Risk Management in Banking ( $4^{\text {th }}$ ed.). John Wiley \& Sons.

Bonner, C., van Lelyveld, I., \& Zymek, R. (2015). Banks' liquidity buffers and the role of liquidity regulation. Journal of Financial Services Research, 48(3), 215-234. https:// econpapers.repec.org/article/kapjfsres/v_3a48_3ay_3a2015_ 3ai_3a3_3ap_3a215-234.htm.

Danila, N., Noreen, U., Azizan, N., Farid, M., \& Ahmad, Z. (2020). Growth opportunities, capital structure, and dividend policy in emerging countries: Indonesia case study. Journal of Asian Finance, Economics, and Business, 7(10), 1-8. https://doi.org// jafeb.2020.vol7.no10.001.

Demirguc-Kunt, A., \& Huizinga, H. (1998). Determinants of commercial bank interest margins and profitability: Some international evidence. Washinton, DC: World Bank e-Library.

Desrochers, J., \& Prefontaine, J. (2008). Comments: Principles for sound liquidity management and supervision. Basel Committee on banking supervision, working group on liquidity, Bank for International Settlements.

Diamond, D. W., \& Dybvig, P. H. (1983). Bank run, deposit insurance, and liquidity. The Journal of Political Economics, 91(3), 401-419. https://www.macroeconomics.tu-berlin.de/ fileadmin/fg124/financial_crises/literature/Diamon_Dybvig_ Bank_Runs_Deposit_Insurance_and_Liquidity.pdf

Diamond, D. W., \& Rajan, R. G. (2001). Liquidity risk, liquidity creation, and financial fragility: A theory of banking. Journal of political Economy, 109(2), 287-327.https://econpapers. repec.org/article/ucpjpolec/v_3a109_3ay_3a2001_3ai_3a2_3a p_3a287-327.htm

Ferrouhi, E., \& Lahadiri, A. (2014). Liquidity determinants of Moroccan banking industry. International Research Journal of Finance and Economics, 118, 102-112. http://www. internationalresearchjournaloffinanceandeconomics.com.
Fleming, D. E. (1974). An analysis of the effects of the practice of liability management by large commercial banks: 1960-1972, Texas -USA. Doctoral dissertation: Texas Tech University.

Gautam, R. (2016). The Determinants of banks liquidity: Empirical evidence on Nepalese commercial banks. Journal of Interdisciplinary Studies, 2(2), 69-78. https://bhlss.files. wordpress.com/2017/02/2.

Gjorgi, G., \& Goran, H. (2019). Determinants of liquidity and its relationship with profitability. The case of Macedonian banking sector. Asian Journal of Economics and Empirical Research, 6(1), 85-92. https://www.asianonlinejournals.com/index.php/ AJEER/article/view/921/1130

Gujarati, D., \& Porter, D. (2009). Basic Econometrics (5th ed.). New York, NY: McGraw-Hill Education.

Goodhart, C. (2008). Liquidity risk management. Financial Stability Review, 11, 39-44. https://econpapers.repec.org/ article/bfrfisrev/2008_3a11_3a6.htm.

Kennedy, P. (2008). A Guide to Econometrics (6th ed.). Malden, MA: Blackwell Publishing.

Khanal, S. (2019). Determinants of liquidity in commercial banks of Nepal. International Journal of Economics and Management Studies, 6(8), 11-19. http://www. internationaljournalssrg.org/IJEMS/2019/Volume6-Issue8/ IJEMS-V6I8P103.pdf

Mashamba, T. (2014). Determinants of commercial banks liquidity: Internal factor analysis. European Journal of Economics and Management, 1(2). http://www.ejemjournal.com/EJEM_2014_ Vol.1_No.2.pdf.

Moore,W. (2009). How do financial crises affect commercial bank liquidity? Evidence from Latin America and the Caribbean, MPRA Paper, 21473. https://ideas.repec.org/p/pra/ mprapa/21473.html

Nguyen, H. D., \& Dang, V. P. (2020). Bank specific determinants of loan growth in Vietnam: Evidence from the CAMELS approach. Journal of Asian Finance, Economics and Business, 7(9), 179-189. doi:10.13106/jafeb.2020.vol7.no9.179.

Ojha, P. R. (2018). Macroeconomics and Bank-Specific factors affecting liquidity: A study of Nepali commercial banks. Journal of Business and Social Sciences, 2(1), 79-87. https:// doi.org/10.3126/jbss.v2i1.22830.

Praet, P., \& Harzberg, V. (2008). Market liquidity and banking liquidity: Linkages, vulnerabilities and the role of disclosure. Financial Stability Review, 11, 95-109. https://econpapers. repec.org/article/bfrfisrev/2008_3a11_3a11.htm.

Rychtarik, T. (2009). Liquidity scenario analysis in the Luxembourg banking sector, BCDL Working Paper, 41. Central Bank of Luxembourg. https://ideas.repec.org/p/bcl/bclwop/bclwp041. html

Saunders, A., Cornett, M. M., \& McGraw, P. A. (2006). Financial institutions management: A risk management approach $\left(8^{\text {th }}\right.$ ed.). New York, NY: McGraw-Hill/Irwin. 
Shah, S., Khan, I., Shah, S., \& Tahir, M. (2018). Factors affecting liquidity of banks: Empirical evidence from Pakistan. International Journal of Theory and Practice, 9(1).

Shamas, G., \& Zainol, Z. (2018). The impact of bank's determinants on liquidity risk: Evidence from Islamic banks in Bahrain. Journal of Business \& Management, 6(1), 1-22. DOI: 10.25255/ jbm.2018.6.1.1.22.

Sheefeni, J., \& Nyambe, J. (2016). Macroeconomic determinants of commercial banks' liquidity. European Journal of Business. European Journal of Business, Economics and Accountancy, 4(5), 19-30. https://www.idpublications.org/ wp-content/uploads/2016/05/.
Tran, S. H., \& Nguyen, C. T. (2020). Financial development, business cycle and bank risk in Southeast Asian Countries. Journal of Asian Finance, Economics and Business, 7(3) 127-135. doi:10.13106/jafeb.2020.vol7.no3.127

Vodova, P. (2011). Determinants of commercial banks' liquidity in Poland. Proceedings of 30th International Conference Mathematical Methods in Economics, 962-967. http:// mme2012.opf.slu.cz/proceedings/pdf/165_Vodova.pdf.

Vodova, P. (2013). Determinants of commercial bank liquidity in Hungary.FinancialInternet Quarterly, e-Finanse, 9(3).https:// www.econstor.eu/bitstream/10419/147078/1/785661964. pdf. 